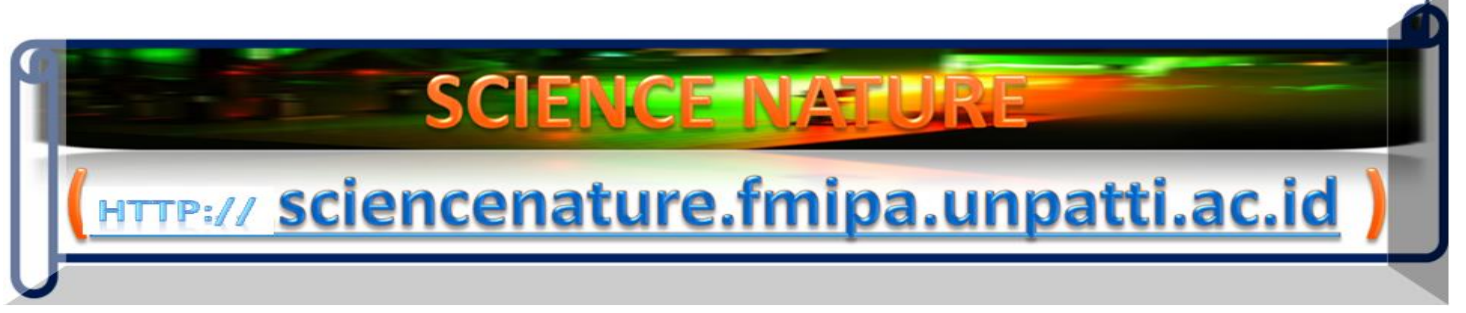

Science Nature 2(3), pp.157-166 (2019)

e-ISSN: 2654-6264

DOI: https://doi.org/10.30598/SNVol2Iss3pp157-166year2019

\title{
Flexible Thin Battery with Fast and Sensitive Voltage Control by a Simple Mechanical Bending: No Energy without Working
}

\author{
Hendry Izaac Elim, ${ }^{1-6, \star}$ Meilladelfia Rahman, ${ }^{1,2}$ Wanda Sari Tutupoho, ${ }^{1,2}$ Randy Rasyid Latuconsina, \\ Aprilia Angel Pattipeilohy, ${ }^{1,2}$ M.V. Reddy, ${ }^{7}$ and Rajan Jose ${ }^{8}$ \\ ${ }^{1}$ Nanomaterials for Photonics Nanotechnology Laboratory (N4PN Lab.), Department of \\ Physics, Faculty of Mathematics and Natural Sciences, Pattimura University, \\ J1. Ir. M. Putuhena, Poka, Ambon, Indonesia 97233 \\ ${ }^{2}$ Nanotechnology Research Center and Innovative Creation (PPNRI-LEMLIT), Research \\ Center of Pattimura University, Pattimura University Campus, \\ Jl. Mr. CHR. Soplanit, Rumah Tiga, Ambon, Indonesia 97234 \\ ${ }^{3}$ Multidisciplinary Research Center of Excellence (MrCE), UNPATTI, \\ J1. Chr. Soplanit, RumahTiga, Ambon, Indonesia 97234 \\ ${ }^{4}$ Theoretical Physics Laboratory, Physics department, Pattimura university, Ambon, Indonesia 97233 \\ ${ }^{5}$ Development and Innovative Center (PPI) of Pattimura University, Indonesia \\ ${ }^{6}$ Specific Laboratory of Electronics and Instrumentation (ELINS Lab.), \\ Physics Department, Pattimura University, Ambon, Maluku, Indonesia 97233 \\ ${ }^{7}$ Centre of Excellence in Transportation Electrification and Energy Storage (CETEES), Hydro-Québec, 1806, \\ Lionel-Boulet blvd., Varennes, Qc, J3X 1S1, Canada \\ ${ }^{8}$ Nanostructured Renewable Energy Materials Laboratory, Faculty of Industrial Sciences \& Technology, \\ Universiti Malaysia Pahang, 26300, Kuantan, Malaysia
}

Received : August 2, 2019

Revised : August 26, 2019

Published : September 1, 2019

Copyright @ All rights are reserved by H.I. Elim, M. Rahman, W.S. Tutupoho, R.R Latuconsina,

A. A. Pattipeilohy M.V. Reddy, and Rajan Jose.

Corresponding author: Email: ‘ hendryelim@gmail.com ; elimheaven@aol.com (HIE) 


\section{Abstract}

The competition among scientists in providing the best need of mobile energy in society has been spread worldwide. This short communication shares a newly simple invention about thin battery with its voltage control simply adjusted by bending it. The changing in battery voltage is quite fast only in few seconds and very sensitive according to the mechanical bending treated into it. Furthermore, the thin battery was fabricated to be water resistant so that it can be applied under water with special technology purposes. This invention is a new beginning for flexible thin battery (FTB) technology which can be implemented in many different activities of daily life such as integrated technology use, medical energy supports, and education smart tools.

Keywords: Flexible Thin battery (FTB), Mechanical bending, Fast and sensitive, Voltage control.
The invented contribution: A novel flexible thin battery (FTB) with a fast and sensitive voltage control using a simple mechanical bending into it.
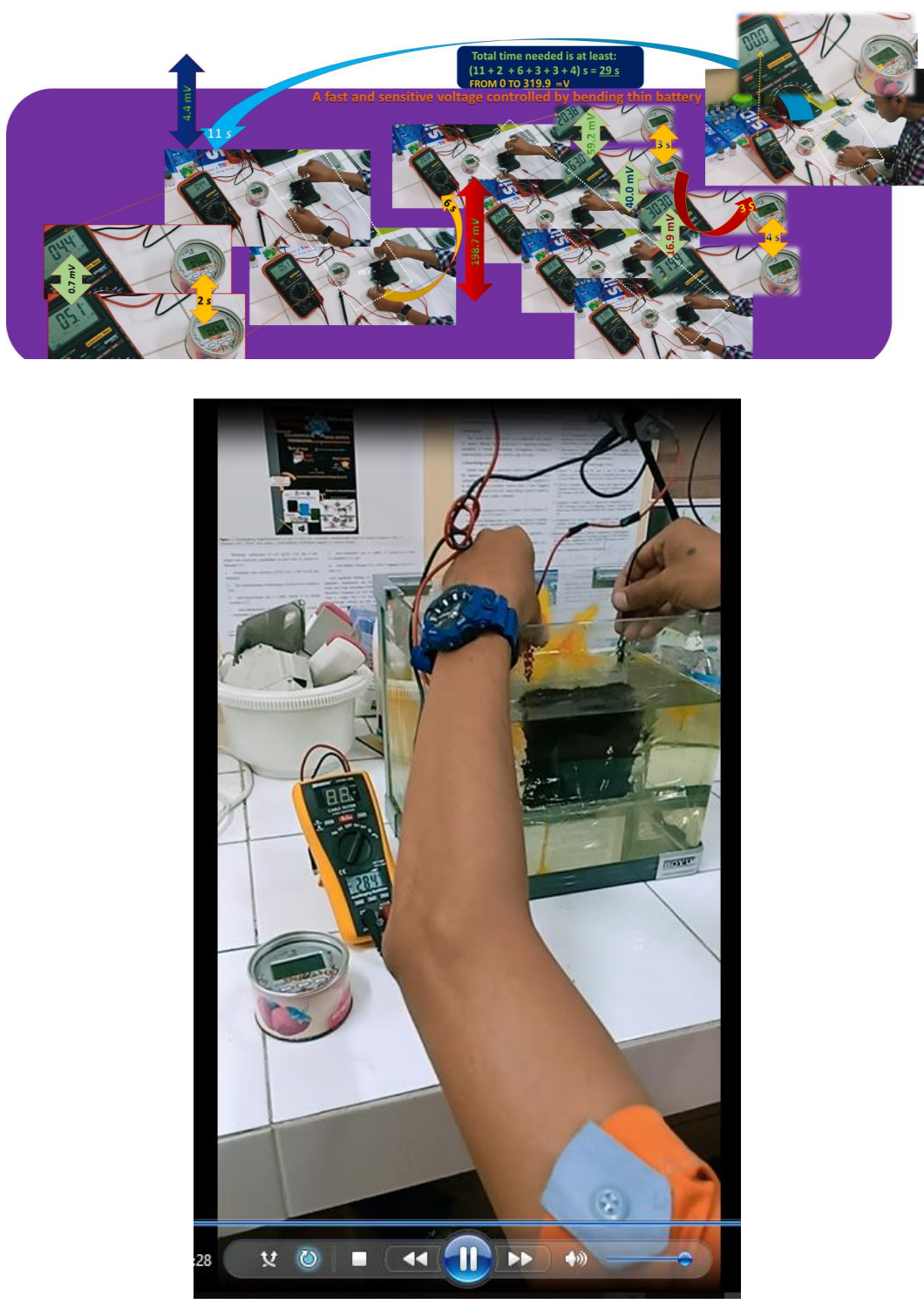

\section{SHORT COMMUNICATION}

Since the first report on a conceptual elastics nanobattery by Elim, et al. in June
2019 [1] based on the deepest former nanobattery developments [2-7], the competition among scientists in providing the best need of mobile energy in this current 
Society 5.0 has been blowout everywhere. The following systematic wisdom and knowledge as well as understanding of nanotechnology by the use of only a very small energy with incredible sensitive optical, mechanical, and electrical responses [3] such as the advanced developments of frontier Li ion battery (LIB) [8-16], the energy storage system in battery [17-22], the Li ion hybrid technology [23-26], the temperature battery influence [27-30], the creative material structures and its composition [31-39], the style of circuit and interface in battery [40-43], the nanoelectrode quality fabrication $[\mathbf{4 4 , 4 5}]$, the mechanical engineering system [46-48], the improvement of cathode materials $[49,50]$, the impedance contributions [51-58], and the tools analysis $[\mathbf{5 9 , 6 0}]$ has made a significant advanced progress in this $21^{\text {st }}$ century multitasking technology. Even though such excellent improvements in nanobattery research and breakthrough have developed the applications in interdisciplinary nanotechnology, there is still opportunity to a novel idea for flexible energy storage with multitasking impacts for another technology and engineering system.

In this paper, we, for the first time, introduce flexible thin battery (FTB) with fast and sensitive voltage control by a simple mechanical bending. Such interesting thin battery was fabricated using a very simple technique and the row materials were from any natural garbage such as used woods, peeled fruit skins of Maluku galoba (Amomum sp.), peanut (Canarium communa) and coconut (Cocos nucifera). Therefore, the cost of such flexible thin battery can be extremely cheap and very useful for many different poor countries consisted of thousands of small islands such as Indonesia, Philippines, Thailand, many nations in Pacific areas, and so forth. This invented battery can be developed to improve its stability of high current and voltage through an extended research on its high energy density, design flexibility, and convenient handling compared to another types of both conventional batteries and sophisticated nanobattery. In addition, present flexible battery may trigger the solution for the main 2 disadvantages of a novel storage device using worldwide LIB technology such as the limitation of suitable electrodes and electrolytes, and the complicated tasks in controlling the electrode-electrolyte interfaces. As a matter of facts, FTB requires both highly conducting and stable confinement thin and flexible solid electrolytes. Based on its simple fabrication technique, there was no need to use a vacuum glove box like in the LIB fabrication technique.

Fabrication technique for this FTB as the output was depicted in Fig. 1 had been through a very simple technique. Firstly, the garbage from the used woods, peeled fruit skins of Maluku galoba (Amomum sp.), peanut (Canarium communa) and coconut (Cocos nucifera), respectively were dried under the sun rays for few weeks. Secondly, the dried row materials were burned on air with the temperature over $500{ }^{\circ} \mathrm{C}$ until they become char like-coal. Thirdly, the char was crushed in few simple steps to be a powder. Furthermore, the thin electrodes made by thin structures of copper $\left.{ }_{29} \mathrm{Cu}\right)$ and aluminum $\left({ }_{13} \mathrm{Al}\right)$ were prepared. Finally, the FTB was fabricated in a special technique covered by a transparent water resistant material. Such smart and brief fabrication method is shown and explained part by part in Fig. 1. 


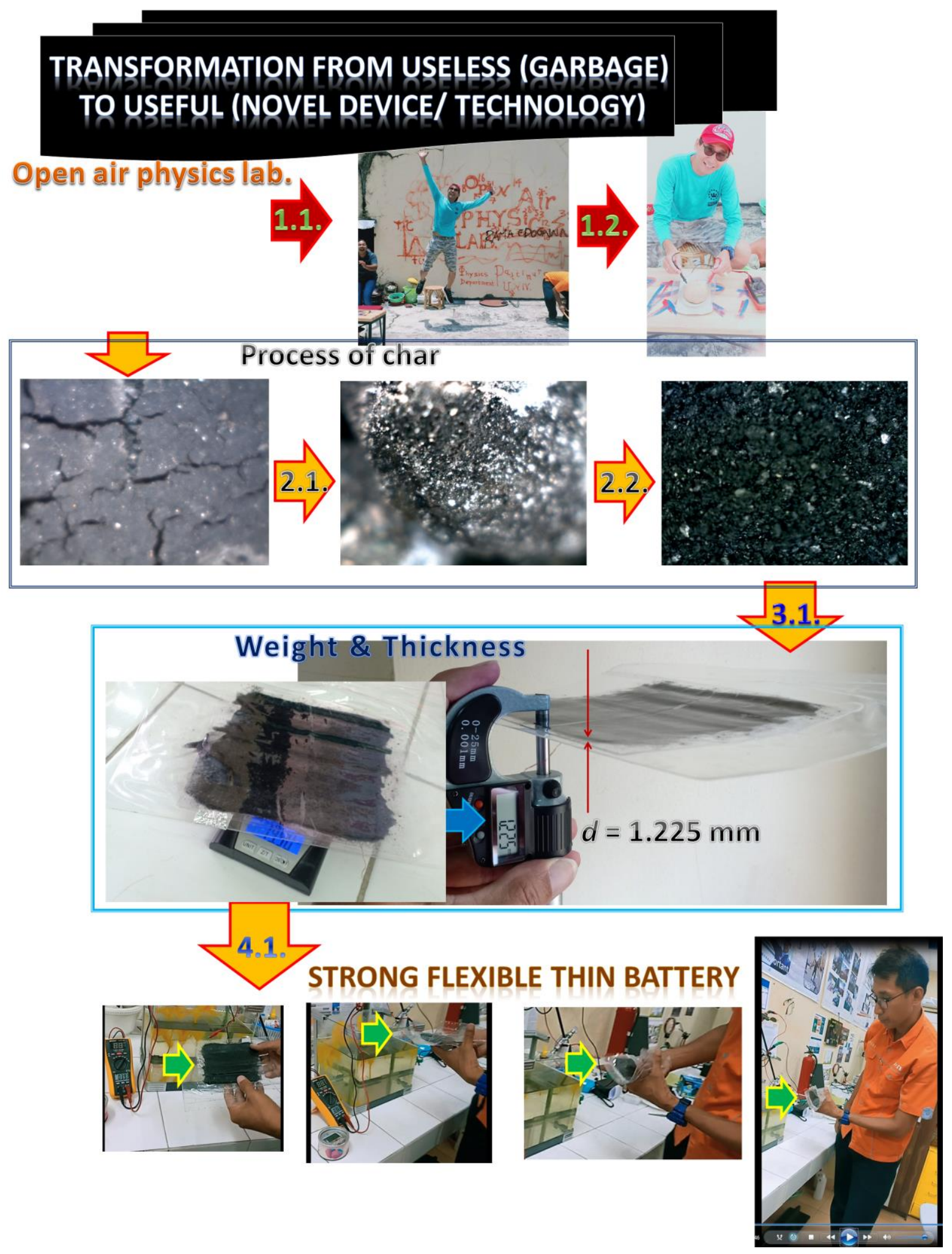

Figure 1. The transformation procedure of simple fabrication technique in realizing a FTB. 


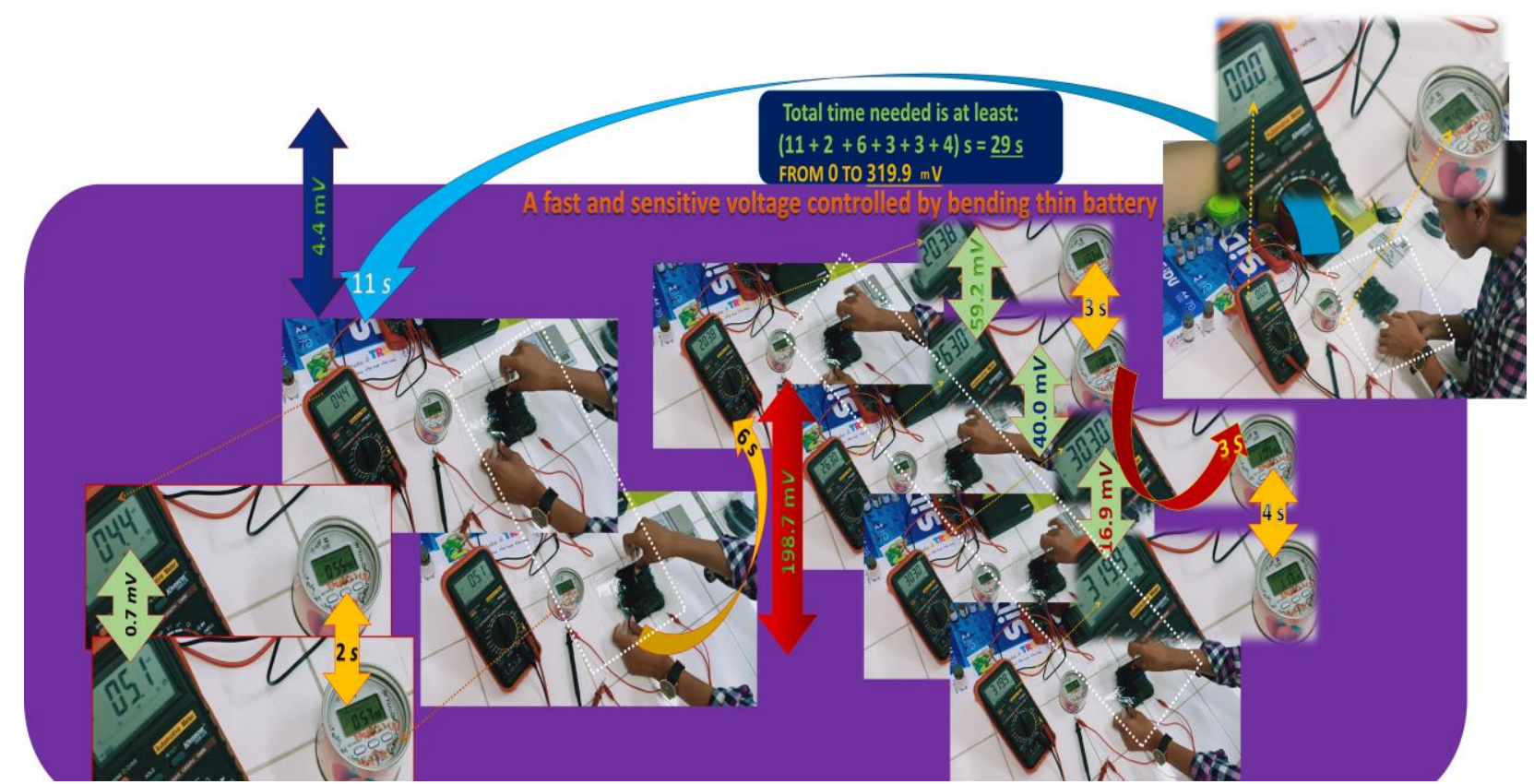

Figure 2. The as fabricated FTB has a voltage control via a simple mechanical bending. According to the shown experimental data, the changing voltage due to such different angle of bending was from 0 $\mathrm{mV}$ to $319.9 \mathrm{mV}$ in just $29 \mathrm{~s}$. The voltage of such FTB will automatically return to zero volt when there is no mechanical energy applied to it.

Figure 2 shows that through a mechanical bending implemented into FTB, the voltage in FTB can be adjusted or controlled. Here, the basic principle of physics in nature is that without work $(\boldsymbol{W})$ or a force $(\boldsymbol{F})$ that moves something in a certain distant $(\boldsymbol{\Delta S})$, there will be no energy $(\boldsymbol{E})$ observed [61]. In order to test the water resistant ability of FTB, in Fig. 3 has been depicted a basic test inside an aquarium for the FTB. Such novel discovery of FTB simple technology is widely applicable in various different activities of daily life such as integrated technology use for special purposes in any mobile electronics devices, medical energy supports, and education smart tools. 


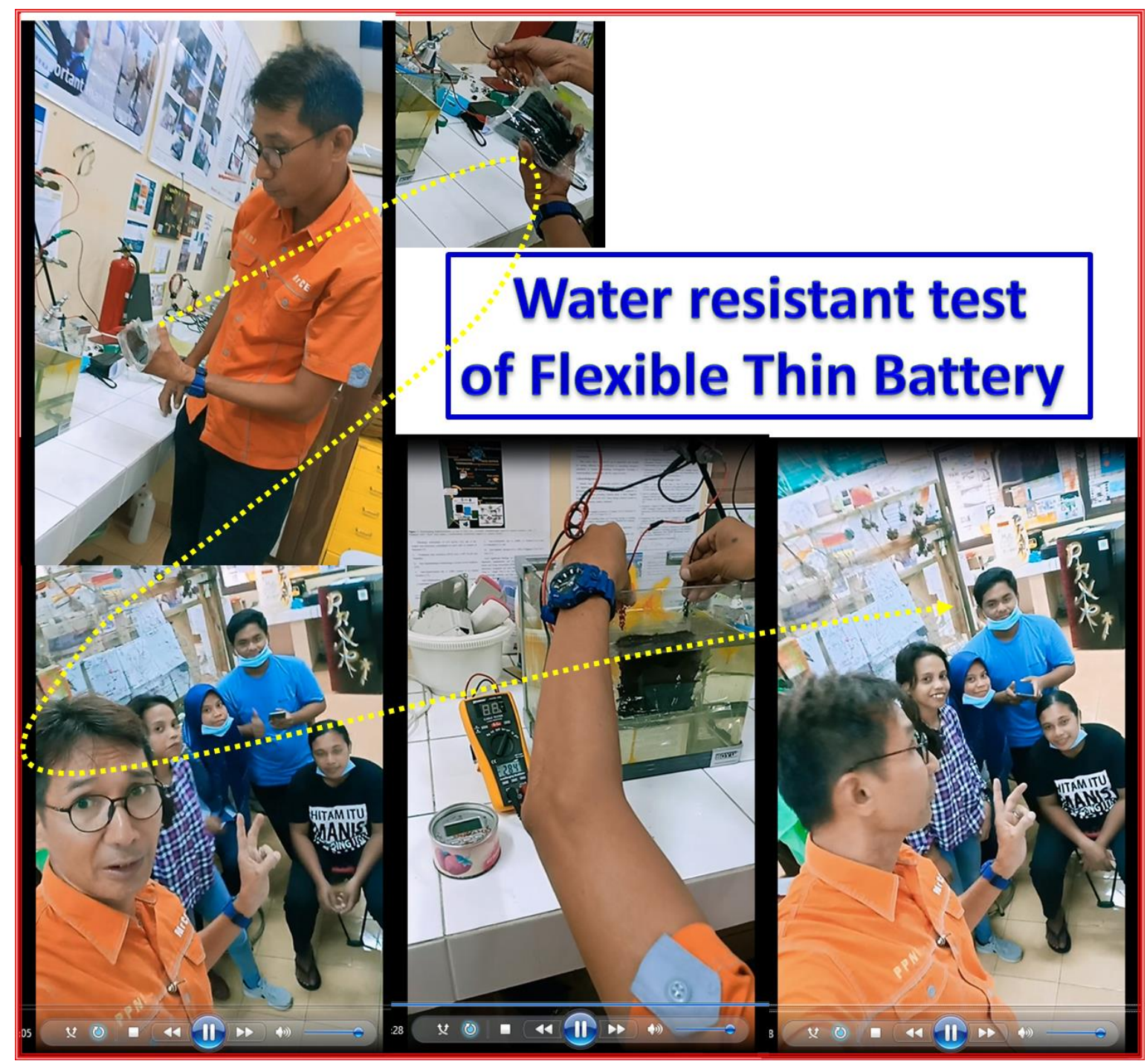

Figure 3. Water resistant test of flexible thin battery in the research center of nanotechnology and innovative creation (PPNRI) at Pattimura university, Ambon, Indonesia.

In conclusion, the as fabricated FTB with thickness of $1.225 \mathrm{~mm}$ with its voltage control adjusted by a simple mechanical bending took about $29 s$ with the total voltage of $319.9 \mathrm{mV}$. Such achievement of storage energy can be improved dramatically by either enlarging the battery material density with nanobattery materials, and flexibility design, or by making large surface for faradaic reaction and short distance for mass and charge diffusion system in the battery. This thin battery system may 
have worldwide multitasking applications after extensive development and collaboration in the near future.

\section{Acknowledgement}

HIE, MVR, and RJ are grateful to the support from the world class research (WCR) research grant of Indonesia Ministry of Higher Education (Ristek-Dikti) plotted in the interval years of 2018 to 2019 with the research project title of "Nanotechnology Strorage Mobile NanoBattery (SMN-B) for Future Energy Sources."

\section{Conflict of Interest}

The researchers involved in this nanobattery technology research declare that there was no any conflict personally in their detail works both ideas and financial support.

\section{References}

[1]. H.I. Elim, M.V. Reddy, and R. Jose, A Frontier 2D Nanobattery: "Improving Challenges (Hotumese) and Development", Science Nature 2(2), pp. 114-121 (2019).

[2]. D. Darbara, M.R. Anilkumard, V. Rajagopalanb, I. Bhattacharyac, H.I. Elim, T. Ramakrishnappaf, F.I. Ezema, R. Jose, M.V. Reddy, Studies on spinel cobaltites, $\mathrm{MCo}_{2} \mathrm{O}_{4}(\mathrm{M}=$ $\mathrm{Mn}, \mathrm{Zn}, \mathrm{Fe}, \mathrm{Ni}$ and $\mathrm{Co}$ ) and their functional properties, Ceramics International 44, pp. 4630-4639 (2018).

[3]. H.I. Elim, Nonlinear Optics and The Frontier of Nanoscience and Nanotechnology, Pattimura University Press, pp. 1-144 (2018). ISBN: 987-602-61906-9-7.

[4]. K.P. Abhilash, P. Christopher Selvin, B. Nalini, R. Jose, Xia Hui, H. I. Elim and M.V. Reddy, Correlation study on temperature dependent conductivity and line profile along the LLTO/LFP-C cross section for all solid-state Lithium-ion batteries, Solid State Ionics 341, 115032 (2019).

[5]. H.I. Elim, A.L. Mapanawang and M.V. Reddy, A Creative Proposal to Improve Woman and Child Health: from the Knowledge of Physical Nanoscience to Nanotechnology Implementation and Products, CPQ Women and Child Health 1(6), pp. 01-11, (2019).
[6]. H.I. Elim and L.Y. Chiang, Nanochip Medicine: Physical Chemistry Engineering, Science Nature 2(1), pp. 86-89 (2019).

[7]. H.I. Elim, Y.W. Zhu, and C.H. Sow, Length Dependence of Ultrafast Optical Nonlinear in Vertically Aligned Multiwalled Carbon Nanotube Films, J. Phys. Chem. C 120(31), 17733-17738 (2016).

[8]. J.B. Goodenough, Y. Kim, Challenges for Rechargeable Li Batteries, Chem. Mater. 22(3), pp. 587-603 (2010). https://doi.org/10.1021/cm901452z.

[9]. K. Kerman, A. Luntz, V. Viswanathan, Y.-M. Chiang and Z. Chen, Review-Practical Challenges Hindering the Development of Solid State Li Ion Batteries, J. Electrochem. Soc. 164, A1731-A1744 (2017). https://doi.org/10.1149/2.1571707jes.

[10]. M.Yang, J. Hou, Membranes in lithium ion batteries,

Membrane. 2, pp. 367-383 (2012).

https://doi.org/10.3390/membranes2030367.

[11]. M.G. Kim, J. Cho, Reversible and high-capacity nanostructured electrode materials for Li-Ion batteries, Adv. Funct. Mater. 20, pp. 1497-1514 (2009). https://doi.org/10.1002/adfm.200801095.

[12]. N. S. Choi, Z. Chen, S. A. Freunberger, X. Ji, Y.K. Sun, K. Amine, G.Yushin, L. F. Nazar, J. Cho, P.G. Bruce, Challenges Facing Lithium Batteries and Electrical Double-Layer Capacitors, Angew. Chem. Int. Ed. 51, pp. 9994-10024 (2012). https://doi.org/10.1002/anie.201201429.

[13]. M. Armand, J.M. Tarascon. Building better batteries, Nat. 451(7), pp. 652-657 (2008). https://doi.org/10.1038/451652a.

[14]. A. R. Armstrong, P.G. Bruce, Synthesis of layered $\mathrm{LiMnO}_{2}$ as an electrode for rechargeable lithium batteries, Nat. 381, pp. 499-500 (1996). https://doi.org/10.1038/381499a0.

[15]. P. Poizot, S. Laruelle, S. Grugeon, L. Dupont, J.M.Tarascon, Nano-sized transition - metal oxides as negative-electrode materials for lithium-ion batteries, Nat. 407, pp 496-499 (2000). https://doi.org/10.1038/35035045.

[16]. K. P. Abhilash, P. Christopher Selvin, B. Nalini, Hui Xia, Stefan Adams, M. V. Reddy, Electrochemical analysis of the carbon-encapsulated Lithium iron phosphate nanochains and their high-temperature conductivity profiles, ACS Omega 3, pp. 6446-6455 (2018). https://doi.org/10.1021/acsomega.8b00527.

[17]. J.G. Werner, G.G. Rodriguez-Calero, H.D. Abruna, and U. Weisner, Block copolymer derived 3-D interpenetrating 
multifunctional gyroidal nanohybrids for electrical energy storage, Energy \& Env. Sci. 11, pp. 1261-1270 (2018).

[18]. M.V. Reddy, C. Yu, F. Jiahuan, K.P. Loh, B.V.R. Chowdari, V. Thavasi, C.H. Sow, S.G. Mhaisalkar, S. Ramakrishna, B.V.R. Chowdari, Molten salt synthesis and energy storage studies on CuCo2O4 and CuO·Co3O4, RSC Adv. 2, p. 9619 (2012).

[19]. M.V. Reddy, Y. Xu, V. Rajarajan, T. Ouyang, B.V.R. Chowdari, Template free facile molten synthesis and energy storage studies on $\mathrm{MCo} 2 \mathrm{O} 4(\mathrm{M}=\mathrm{Mg}, \mathrm{Mn})$ as anode for $\mathrm{Li}$-ion batteries, $\boldsymbol{A C S}$ Sustain. Chem. Eng. 3, pp. 3035-3042 (2015).

[20]. Shihan Yan, K. P. Abhilash, Lingyu Tang, Mei Yang, Yifan Ma, Qiuying Xia, Qiubo Guo, Hui Xia, Research Advances of Amorphous Metal Oxides in Electrochemical Energy Storage and Conversion, Small 15, pp. 1804371 (1-30) (2018). https://doi.org/10.1002/smll.201804371.

[21]. M. R. Palacin, Recent advances in rechargeable battery materials: a chemist's perspective, Chem. Soc. Rev. 38, pp. 2565-2575 (2009). https://doi.org/10.1039/B820555H.

[22]. T. Cheisson and E.J. Schelter, Rare earth elements: Mendeleev's bane, modern marvels, Science pp. 489-493 (2019).

[23]. A. Maurel, M. Courty, B. Fleutot, H. Tortajada, K. Prashantha, M. Armand, S. Grugeon, S. Panier, and L. Dupont, Highly loaded graphite-polylactic acid composite-based filaments for lithium-ion battery three dimensional printing, Chem. Mater. 30(21), pp. 7484-7493 (2018).

[24]. X. Gao, C.A.J. Fisher, T. Kimura, Y.H. Ikuhara, H. Moriwake, A. Kuwabara, H. Oki , T. Tojigamori, R. Huang, Lithium atom and A-site vacancy distributions in lanthanum lithium titanate,

Chem. Mater. 25(9), pp. 1607-1614 (2013). https://doi.org/10.1021/cm3041357.

[25]. J.B. Goodenough, Y. Kim, Challenges for rechargeable Li batteries. Chem. Mater. 22, pp. 587-603 (2010). https://doi.org/10.1021/cm901452z.

[26]. D. Qian, B. Xu, H.M. Cho, T. Hatsukade, K. J. Carroll, Y. S. Meng, Lithium Lanthanum Titanium Oxides: A Fast Ionic Conductive Coating for Lithium-Ion Battery Cathodes, Chem.

Mater. 24(14), pp. $2744-2751$ (2012).

https://doi.org/10.1021/cm300929r.

[27]. K.P.Abhilash, P.ChristopherSelvin, B.Nalini, K.Somasundaram, P.Sivaraj, A.Chandra Bose, Study of the temperature dependent transport properties in nanocrystalline lithium lanthanum titanate for lithium ion batteries, J. Phys. Chem.
Solids. 91, pp. 114-121 (2016),

http://dx.doi.org/10.1016/j.jpcs.2015.12.015.

[28]. P. Sivaraj, K. P. Abhilash, B. Nalini, P. Balraju, Sudheer Kumar Yadav, S. Jayapandi, P. Christopher Selvin, Structure, dielectric, and temperature-dependent conductivity studies of the $\mathrm{Li}_{2} \mathrm{FeSiO}_{4} / \mathrm{C}$ nano cathode material for lithium-ion batteries, Ionics 25, pp. 2041-2056 (2019). https://doi.org/10.1007/s11581-018-2685-1.

[29]. N. Iltchev, Y. Chen, S. Okada, J. Yamaki, $\underline{\mathrm{LiFePO}}_{4} \underline{\text { storage at }}$ room and elevated temperatures, J. Power sources 119-121, pp. 749-754 (2003). https://doi.org/10.1016/S0378-7753(03)00215-5.

[30]. P. Perumal, K. P Abhilash, P. Sivaraj, P.C. Selvin, Study on Mg-ion conducting solid biopolymer electrolytes based on tamarind seed polysaccharide for magnesium ion batteries, Materials Research Bulletin 뇨, p. 110490 (2019). https://doi.org/10.1016/j.materresbull.2019.05.015.

[31]. M.Kopec, A.Yamanda, G. Kobayashi, S. Nishimura, Structural and magnetic properties of $\mathrm{Li}_{\mathrm{x}}\left(\mathrm{Mn}_{\mathrm{y}} \mathrm{Fe}_{1-\mathrm{y}}\right) \mathrm{PO}_{4}$ electrode materials for Li-ion batteries, J. Power sources. 189, pp. 1154-1163 (2009). https://doi.org/10.1016/j.jpowsour.2008.12.096.

[32]. B. Antoniassi, A.H.M. Gonzalez, S.L. Fernandes, C.F.O. Graeff, Microstructural and electrochemical study of $\mathrm{La}_{0.5} \mathrm{Li}_{0.5} \mathrm{TiO}_{3}$, Mater. Chem. Phys. 127, pp. 51-55 (2011). https://doi.org/10.1016/j.matchemphys.2010.12.021.

[33]. J. Ibarra, A.Vareza, C. Leon, J. Santamaria, L.M.

Torres-Martinez, J. Sanz, Influence of composition on the structure and conductivity of the fast ionic conductors $\mathrm{La}_{2 / 3-x}$ $\mathrm{Li}_{3 \mathrm{x}} \mathrm{TiO}_{3}(0.03 \leq 3 x \leq 0.167)$, Solid State Ion. 134(3-4), pp. 219-228 (2000). https://doi.org/10.1016/S0167-2738(00)00761-X.

[34]. Y. Liang, L. Ji, B. Guo, Z. Lin, Y. Yao, Y. Li, M. Alcoutlabi, Y. Qiu, X. Zhang, Preparation and electrochemical characterization of ionic-conducting lithium lanthanum titanate oxide/polyacrylonitrile submicron composite fiber-based lithium-ion battery separators, J. Power Sources. 196, pp. 436-441 (2011). https://doi.org/10.1016/j.jpowsour.2010.06.088.

[35]. O. Bohnke, Q. N. Pham, A. Boulant, J. Emery, T. Salkus, M. Barre, $\mathrm{H}^{+} / \mathrm{Li}^{+}$exchange property of $\mathrm{Li}_{3 \mathrm{X}} \mathrm{La}_{2 / 3-\mathrm{X}} \mathrm{TiO}_{3}$ in water and in humid atmosphere. Solid State Ion. 188(1), pp. 144-147 (2011). https://doi.org/10.1016/j.ssi.2010.09.058. 
[36]. C. W. Ban, G. M. Choi, The effect of sintering on the grain boundary conductivity of lithium lanthanum titanates, Solid State Ion. 140(3-4), pp. 285-292 (2001). https://doi.org/10.1016/S0167-2738(01)00821-9.

[37]. K. Y. Yang, H. W. Wang, K. Z. Fung, Roles of lithium ions and $\mathrm{La} / \mathrm{Li}$-site vacancies in sinterability and total ionic conduction properties of polycrystalline $\mathrm{Li}_{3} x \mathrm{La}_{2 / 3} x \mathrm{TiO}_{3}$ solid electrolytes $(0.21 \leq 3 x \leq 0.50)$, J. Alloys Compd. 458(1-2), pp. 415-424 (2008). https://doi.org/10.1016/j.jallcom.2007.03.130.

[38]. Y.Q. Cheng, Z.H. Bi, A. Huq, M. Feygenson, C.A. Bridges, M.P. Paranthaman, B.G. Sumpter, An integrated approach for structural characterization of complex solid state electrolytes: the case of lithium lanthanum titanate, J. Mat. Chem. A. 2, pp. 2418-2426 (2014). https://doi.org/10.1039/C3TA14433J.

[39]. H.X. Geng, A. Mei, C. Dong, Y.H. Lin, C.W. Nan, Investigation of structure and electrical properties of $\mathrm{Li}_{0.5} \mathrm{La}_{0.5} \mathrm{TiO}_{3}$ ceramics via microwave sintering, J. Alloys. Compd. 481, pp. 555-558 (2009). https://doi.org/10.1016/j.jallcom.2009.03.038.

[40]. D. Fauteux, Formation of a passivating film at the lithium-PEO-LiCF${ }_{3} \mathrm{SO}_{3}$ interface. Solid State Ion. 17, pp. 133-138 (1985). https://doi.org/10.1016/0167-2738(85)90061-X.

[41]. H. Matsuia, T. Nakamuraa, Y. Kobayashib, M.Tabuchic, Y. Yamada, Open-circuit voltage study on $\mathrm{LiFePO}_{4}$ olivine cathode, J. Power Sources 195, pp. 6879-6883 (2010). https://doi.org/10.1016/j.jpowsour.2010.04.072.

[42]. I-Wei Chen, Mobility control of ceramic grain boundaries and interfaces, Mater Sci. Eng. A. 166, pp. 51-58 (1993). https://doi.org/10.1016/0921-5093(93)90309-3.

[43]. K. H. Kim, Y. Iriyama, K. Yamamoto, S. Kumazaki, T.Asaka, K. Tanabe, C. A.J. Fisher, T. Hirayama, R. Murugan, Z. Ogumi, Characterization of the interface between $\mathrm{LiCoO}_{2}$ and $\mathrm{Li}_{7} \mathrm{La}_{3} \mathrm{Zr}_{2} \mathrm{O}_{12}$ in an all solid state rechargeable lithium battery. $J$.

Power sources. 196, pp. 764-767 (2011). https://doi.org/10.1016/j.jpowsour.2010.07.073.

[44]. K.P.Abhilash, P.Sivaraj, P.ChristopherSelvin, B.Nalini, K.Somasundaram, Investigation on spin coated LLTO thin film nano-electrolytes for rechargeable lithium ion batteries, Ceram. Int. 41, pp. 13823-13829 (2015). http://dx.doi.org/10.1016/j.ceramint.2015.08.067.

[45]. K.P. Abhilash, P. Christopher Selvin, B. Nalini, P. Nithyadharseni, B.C. Pillai, Investigations of pure and Ag doped lithium lanthanum titanate (LLTO) ceramic electrolytes for rechargeable lithium-ion batteries, Ceram. Int. 39, pp. 947-952 (2013). https://doi.org/10.1016/j.ceramint.2012.07.011.

[46]. A. Sakuda, A. Hayashi, M. Tatsumisago, Sulfide solid electrolyte with favorable mechanical property for all-solid-state lithium battery, $\quad$ Sci. $\quad$ Rep. 3, p. $2261 \quad$ (2013). https://doi.org/10.1038/srep02261.

[47]. J.E. Weston, B. C. H. Steele, Effects of inert fillers on the mechanical and electrochemical properties of lithium salt-poly(ethylene oxide) polymer electrolytes. Solid State Ion. 7, pp. 75-79 (1982). https://doi.org/10.1016/0167-2738(82)90072-8.

[48]. A. Sakuda, A. Hayashi, Y. Takigawa, K. Higashi, M. Tatsumisago, Evaluation of elastic modulus of Li2S-P2S5 glassy solid electrolyte by ultrasonic sound velocity measurement and compression test. J. Ceram. Soc. Jpn. 121, pp. 946-949 (2013). https://doi.org/10.2109/jcersj2.121.946

[49]. Zhao-Rong Chang, Hao-Jie Lv, Hong-Wei Tang, Hua-Ji Li, Xiao-Zi Yuan, Hajiang Wang, Synthesis and characterization of high-density $\mathrm{LiFePO}_{4} / \mathrm{C}$ composites as cathode materials for lithium-ion batteries, Electrochim. Acta. 54, pp. 4595-4599 (2009). https://doi.org/10.1016/j.electacta.2009.03.063.

[50]. Yan Cui, Xiaoli Zhao, Ruisong Guo, Enhanced electrochemical properties of $\mathrm{LiFePO}_{4}$ cathode material by $\mathrm{CuO}$ and carbon co-coating, J. Alloys Compd. 490, pp. 236-240 (2010). https://doi.org/10.1016/j.jallcom.2009.09.165.

[51]. P. Jasinski, V. Petrovsky, T. Suzuki, H. U. Anderson, Impedance Studies of Diffusion Phenomena and Ionic and Electronic Conductivity of Cerium Oxide. J. Electrochem. Soc. 152, pp. J27-J32 (2005). https://doi.org/10.1149/1.1861174.

[52]. D.C. Sinclair, Characterization of Electro-materials using ac Impedance Spectroscopy, Bol. Soc. Esp. Ceram. Vidrio 34 (2), pp. 55-65 (1995). boletines.secv.es/upload/199534055.pdf

[53]. C. C. Hunter, D. C. Sinclair, A. R. West, A. Hooper, A.C. impedance studies of the lithium/polymer electrolyte interface in solid-state lithium cells, J. Power Sources. 24, pp. 157-164 (1988). https://doi.org/10.1016/0378-7753(88)80099-5.

[54]. M. Keddam, C.Kuntz, H.Takenouti, D.Schuster, D.Zuili, Exfoliation corrosion of alumininium alloys examined by electrode impedance, Electrochim Acta. 42, pp. 87-97 (1997). https://doi.org/10.1016/0013-4686(96)00170-3. 
[55]. X. Qian, N. Gu, Z. Cheng, X. Yang, E. Wang, S. Dong, Impedance study of (PEO) ${ }_{10} \mathrm{LiClO}_{4}-\mathrm{Al}_{2} \mathrm{O}_{3}$ composite polymer electrolyte with blocking electrodes, Electrochim. Acta. 46, pp. 1829-1836 (2001). https://doi.org/10.1016/S0013-4686(00)00723-4.

[56]. J.T.S. Irvine, D.C. Sinclair, A.R.West, Electroceramics : Characterization by Impedance Spectroscopy. Adv. Mater. 2, pp. 132-138 (1990). https://doi.org/10.1002/adma.19900020304.

[57]. E. Barsoukov, J.R.Macdonald, Impedance Spectroscopy: Theory, Experiment, and Applications. $2^{\text {nd }}$ Edition. Hoboken, New Jersey. John Wiley \& Sons; pp 1-616 (2005).

[58]. M. Ciureanu, H. Wang, Electrochemical Impedance Study of Electrode-Membrane Assemblies in PEM Fuel Cells: I. Electro-oxidation of $\mathrm{H}_{2}$ and $\mathrm{H}_{2} / \mathrm{CO}$ Mixtures on Pt-Based Gas-Diffusion Electrodes, J. Electrochem. Soc. 146, 4031-4040 (1999). https://doi.org/10.1149/1.1392588.

[59]. J.I. Goldstein, D.E. Newbury, D.C. Joy, C.E. Lyman, P. Echlin, E. Lifshin, L. Sawyer, J.R. Michel, Scanning Electron Microscopy and X-ray Microanalysis. $3^{\text {rd }}$ Edition. New York. Springer; pp 491-451 (2003).
[60]. A. Brazier, L. Dupont, L. Laffont, et al., First cross-section observation of an all solid-state lithium-ion "nanobattery" by transmission electron microscopy, Chem. Mater. 20(6), (2008).

[61]. H.I,. Elim, METODE FISIKA EKSPERIMEN: PELENGKAP TEORI FISIKA, Pattimura University Press, pp. 1-155 (2018). ISBN: 978-602-5943-05-8. Printed in 2019.

\section{'Corresponding Authors CV:}

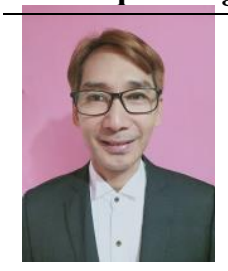

AAssoc.Prof. Hendry Izaac Elim, Ph.D is one of Indonesia remarkable physicists. His works have various impacts especially related to multitasking physics in universe. In the last 19 years of his career, Dr. Elim has published over 50 papers by educating over 75 research students in highly cited journals indicated by about 22 of them in Q1 journals as well as 16 in Q2 journals based on SCOPUS or Web of Science (WoS). In 2019, Dr. Elim has achieved the highest number of publications in his field with the number of paper in a year was 12. Such excellence research contributions have paid worldwide attentions in his overall citations of up to $\sim \mathbf{3 1 5 3}$ based on Google Scholar. In addition, Dr. Elim high quality life with the development of science and technology has actually been contributed by a series of faithful collaboration with many different students, researchers, senior scientists and distinguished professors from many different nations on earth. In addition, Dr Elim have published 3 text books in physics about the guidance for B.Sc thesis, experimental physics and frontier physics in nanoscience, nanotechnology, as well as herbal medicine. ORCID of H I E: 0000-0002-4272-7115

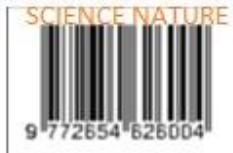

